Hum. Hered. 1990;40:I-VI

\title{
Contents, Vol. 40, 1990
}

\section{Editor}

L. Beckman, Umeå Associate Editors

C.R. Cloninger, St. Louis, Mo. P.M. Coneally, Indianapolis, Ind. H. Hoehn, Würzburg

Editorial Board

K. Berg, Oslo

L.L. Cavalli-Sforza, Stanford, Calif.

A. de la Chapelle, Helsinki

J. Dausset, Paris

T.J. David, Manchester

B. Dutrillaux, Paris

F.C. Fraser, Montreal

N. Freire-Maia, Curitiba

J. Frézal, Paris

R. Grubb, Lund P.A. Jacobs, New York, N.Y. Margareta Mikkelsen, København F. Mitelman, Lund

N.E. Morton, New York, N.Y.

J. Mohr, København

A.E. Mourant, London

J.V. Neel, Ann Arbor, Mich.

U. Pettersson, Uppsala

Marianne Rasmuson, Umeå

D.L. Rimoin, Los Angeles, Calif.

L.D. Sanghvi, Bombay

M. Siniscalco, New York, N.Y.

F. Vogel, Heidelberg

D.J. Weatherall, Oxford

R.L. White, Salt Lake City, Utah

M. Whittaker, Exeter

KARGEK

Contents Vol. 40,1990

No. 1 Original Paper

Ethnic-Specific Allelic Variation within the D1Z2 Locus

Tynan, K.M.; Field, L.L.; Hoar, D.I 1 
Malaria and Glucose 6-Phosphate Dehydrogenase Deficiency in Populations with High and Low Spleen Rates in Madang, Papua New Guinea

Brabin, L.; Brabin, B.J 15

Alpha-1-Antitrypsin (Protease Inhibitor) Phenotypes and Longevity

Muir, A.; Whitfield, J.B 22

Genetic-Epidemiologic Study of Haemophilia A and B in Hungary

István, L.; Czeizel, A.; Kerényi, M.; Tóth, A.M.; Domby, E 29

GC Subtyping and HIV Infection in a Spanish Population: No Evidence of an Association between GC Subtypes and AIDS

Alonso, A.; Montesino, M.; Iturralde, M.J.; Vallejo, G.; Sancho, M.; Tena, G.; Varela, J.M.;

Saiz, A.; Nájera, R 34

Restriction Site Polymophisms at the Human HepG2 Glucose Transporter Gene Locus in

Caucasian and West Indian Subjects with Non-Insulin-Dependent Diabetes mellitus

Li, S.-R.; Oelbaum, R.S.; Bouloux, P.M.G.; Stocks, J.; Baroni, M.G.; Galton, DJ. 38 Formal and Population Genetics of F13A and FUCA1 Polymophisms in Northern Portugal

Prata, M.J.; Amorim, A

45

Short Communications

Genetic Variation of Alpha-2-HS-Glycoprotein in the Kyushu District of Japan: Descrip

tion of Three New Rare Variants

Fukuma, Y.; Kashimura, S.; Umetsu, K.; Yuasa, I.; Suzuki, T

A Population Study of Leukocyte Enzymes (GOT2, ME2 and PGM3) in Galicia (NW Spain)

Llano, C; Caeiro, J.L.B.; Boán, F 52

Factor H Polymorphism, Typing by Isoelectrofocusing and Immunoblotting: No Associa tion with Rheumatoid Arthritis

Zhou, M.; Larsen, B 55

A New Complement Factor B Variant (BF S075) in Japanese

Nishimukai, H.; Maruyama, I.; Takenaga, S.; Kitamura, H.; Mizutani, J.; Shinomiya, T. 58

Contents III

No. 2 Original Paper

Frequency Distribution of the Alleles of Several Variable Number of Tandem Repeat DNA

Polymorphisms in the Italian Population

Gasparini, P.; Trabetti, E.; Savoia, A.; Marigo, M.; Pignatti, P.F 61

A Genetic Study of Immunoglobulin E and Atopic Disease Based on Families Ascertained through Asthmatic Children

Parks, T.; Felix, K.; Rice, T.; Subbarao, P.V.; Marimuthu, K.M.; Rao, D.C 69

Minisatellite DNA Profiles: Rapid Sample Identification in Linkage Analysis

Telenius, H.; Clark, J.; Marcus, E.; Royle, N.; Jeffreys, A.J.; Ponder, B.A.J.; Mathew, C.G.P. 77

Partial Trisomy of Chromosome 18 (pter $\rightarrow$ q12) following a Familial 18;21 Translocation

$\operatorname{rcp}(18 ; 21)(\mathrm{ql} ; \mathrm{q} 11)$

Binkert, F.; Stranzinger, J.; Schinzel, A 81

Study of Alpha-Thalassemia in Northeastern Thailand at the DNA Level

Hundrieser, J.; Laig, M.; Yongvanit, P.; Sriboonlue, P.; Sanguansermsri, T.; Kühnau, W.;

Pape, M.; Flatz, G 85

Salivary Proline-Rich Protein Polymorphisms in Chinese, Malays and Indians in

Singapore

Shintani, M.; Minaguchi, K.; Lim, K.A.; Hashimoto, M.; Suzuki, K 
Thermolabile Hexosaminidase (Hex) B: Diverse Frequencies among Jewish Communities and Implication for Screening of Sera for Hex A Deficiencies

Navon, R.; Adam, A 99

Genetic Linkage Is Excluded for the D2-Dopamine Receptor $\lambda$ HD2G 1 and Flanking Loci on Chromosome 1 Iq22-q23 in Tourette Syndrome

Devor, E.J.; Grandy, D.K.; Civelli, O.; Litt, M.; Burgess, A.K.; Isenberg, K.E.; Wetering, B.J.M. van de; Oostra, B 105

No Evidence for Linkage between Chromosome 5 Markers and Schizophrenia

Aschauer, H.N.; Aschauer-Treiber, G.; Isenberg, K.E.; Todd, R.D.; Knesevich, M.A.;

Garver, D.L.; Reich, T.; Cloninger, C.R 109

Short Communications

Alpha-1-Antitrypsin Types and Serum Levels in Toxoplasmosis

Daneshmand, P.; Farhud, D.D 116

Is There a Sex-Phenotype Association for Esterase D (EC 3.1.1.1)?

Moro-Furlani, A.M.; Cabello, P.H.; Krieger, H 118

No. 3 Original Paper

Genetic Polymorphism of Human Factor H ( $ß 1 \mathrm{H}$ Globulin)

Nakamura, S.; Ohue, O.; Sawaguchi, A 121

Genetic Studies of Human Apolipoproteins. XIII. Quantitative Polymorphism of Apolipoprotein C-III in the Mayans of the Yucatan Peninsula

Ferrell, R.E.; Kamboh, M.I.; Majumder, P.P.; Valdez, R.; Weiss, K.M 127

Genetic Markers in Schizophrenia: ACPI, ESD, TF and GC Polymorphisms

Fañanás, L.; Moral, P.; Marti Tusquets, J.L.; Bertranpetit, J 136

Transferrin Subtypes and Spontaneous Abortion in a Chinese Population

Saha, N.; Tay, J.S.H.; Murugasu, B.; Wong, H.B 141

Isolation and Characterization of DNA Sequences from Flow-Sorted Human Chromosome 22 Libraries

Metzdorf, R.; Herzog, R.; Göttert, E.; Blin, N

IV Contents

Heterogeneity of the Silent Gene for Plasma Cholinesterase. Immunological Studies

Whittaker, M.; Jones, J.; Braven, J 153

Serum Ferritin as a Marker of Affection for Genetic Hemochromatosis

Borecki, LB.; Rao, D.C.; Yaouanq, J.; Lalouel, J.M 159

Segregation and Sporadic Cases of Duchenne Muscular Dystrophy in the Henan Province,

China

Fu, W.; Barbujani, G 167

Possible Protective Effect against Chronic Obstructive Airways Disease by the GC 2

Allele

Home, S.L.; Cockcroft, D.W.; Dosman, J.A 173

Beta-Globin Gene Haplotypes in the Saudi Sickle Cell Anaemia Patients

El-Hazmi, M.A.F 177

Short Communications

Second Family Case of Duplication of the IF and 1A2 Genes in the Vitamin D-Binding

Protein (GC) System

Sawazaki, K.; Yamaba, T.; Yasuda, T.; Mizuta, K.; Kishi, K

Studies of Association between Some Genetic Systems (ABO, MN, EsD, GLO, C3 and Hp) 
Mohan Raj, B.K.; Damodaran, C; Chandra Sekharan, P 190

No. 4 Review

Genetic Studies of Human Apolipoproteins. XV. An Overview of IEF Immunoblotting

Methods to Screen Apolipoprotein Polymorphisms

Kamboh, M.I.; Ferrell, R.E 193

Original Paper

Inbreeding Effects on Reproductive Outcome in a Sudanese Population

Saha, N.; Hamad, R.E.; Mohamed, S 208

Evolution at HLA: Possible Explanations for the Deficiency of Homozygotes in

Two Populations

Hedrick, P.W 213

New AUelic Product of the PRH 1 Locus Coding for Salivary Acidic Proline-Rich Proteins

Minaguchi, K.; Shintani, M.; Suzuki, K 221

Sex-Linked Determinants for IgM?

McGue, M.; Borecki, LB.; Gerrard, J.W.; Rao, D.C 231

Evidence of a Rare Gene for Low Systolic Blood Pressure in the Framingham

Heart Study

Carter, C.L.; Kannel, W.B 235

Anti-Gerbich Antibodies and Gerbich-Negative Dantu-Positive Red Blood Cells in a

Woman from South Africa

Moores, P.; Beer, R. de.; Marais, L; Levene, C; May, R.; Toit, E. du

Short Communications

Recognition of the $\mathrm{E}^{3} / 8 \mathrm{E}^{7} / 8$ Homozygote for Plasma Cholinesterase

Whittaker, M.; Britten J.J 247

Restriction Fragment Length Polymorphism (RFLP) at the DNF15S2 Locus in

Three Ethnic Groups of Singapore

Saha, N.; Tay, J.S.H.; Carritt, B 250

Contents V

No. 5 Original Paper

Serum Gc, Hp and $\alpha 2 \mathrm{HS}$ Phenotypes in Human T-Lymphotropic Leukemia Virus Type I Infection

Ogata, M.; Iwasaki, M.; Kubo, S.; Nakasono, I.; Suyama, H.; Kinoshita, K.; Ikeda, S.;

Momida, S.; Ichimara, M 253

Wd(a+) Red Blood Cells in Two Sisters of a Hei//om Khoisan Family in Namibia

Moores, P.; Smart, E.; Marks, M.; Botha, M.C 257

Serogenetic Variation in Four Caste Populations of Haryana, India

Kushwaha, K.P.S.; Chahal, S.M.S.; Basnal, U.S.; Chugh, O.P.; Sarojani 262

Orosomucoid (ORM) Typing by Isoelectric Focusing: An Analysis of ORM Haplotypes

Yuasa, I.; Umetsu, K.; Suenaga, K.; Iha, M.; Hirata, H.; Ikebuchi, J267

Association of $\mathrm{C} 3$ and C4A Complement Types with Familial Amyloidotic Poly-neuropathy

Nylander, P.-O; Beckman, L.; Holmgren, G.; Steen, L 272

Ten Homozygous -D- Individuals in One Italian Village

Mora, M.L.; Botti, G.; Lomas, C 278

ß-Globin Gene Haplotypes in Polynesians Are Predominantly Southern Chinese in Type

Trent, R.J.; Ferguson, V.; Hertzberg, M.S.; Rutherford, J.; Mickleson, K.N.P 285

HLA-Associated Susceptibility to Acquired Immune Deficiency Syndrome in HIV-1-Sero- 
positive Subjects

Kaplan, C; Muller, J.Y.; Doinel, C; Lefrère, J.J.; Paquez, F.; Rouger, P.; Salmon, D.;

Salmon, C 290

Short Communications

Restriction Fragment Length Polymorphism of the D5S4 Locus in Italy

Palmarino, R.; Mantuano, E.; Gambino, I.; Lucarelli, P 299

Two New Orosomucoid (ORM2) Variants in Japanese

Fukuma, Y.; Kashimura, S.; Umetsu, K.; Yuasa, I.; Nakano, B.; Nakasono, 1302

Presymptomatic Exclusion of Myotonic Dystrophy in a One-Generation Pedigree of Half-

Siblings

Ott, J.; Caesar, J.; Mächler, M.; Schinzel, A.; Schmid, W 305

Red-Cell Enzyme Polymorphisms in the Reggio Calabria Province (Italy)

Rickards, O.; Tartaglia, M.; Biondi, G.; Scano, G.; Walter, H.; De Stefano, G.F. ... 308

Distribution of Human Zn-Alpha-2-Glycoprotein Types in Chinese and Korean Popula tions

Ding, M.; Umetsu, K; Nakayashiki, N.; Choi, W.Y.; Jia, J.; Suzuki, T 311

No. 6 Original Paper

Diversity of Some Gene Frequencies in European and Asian Populations. VI. Geographic

Patterns of PGM and ACP

Farabegoli, A.; Barbujani, G 313

Heterozygosity Effects in Studies of Genetic Markers and Disease

Beckman, L.; Fröhlander, N 322

Orosomucoid (ORM1 and ORM2) types in the Spanish Basque Country, Galicia and

Northern Portugal

Montiel, M.D.; Carracedo, A.; Blazquez-Caeiro, J.L.; Andrade-Vide, C 330

Transferrin C Subtypes and Ethnic Heterogeneity in Sweden

Sikström, C; Nylander, P.-O 335

VI

Contents

Variability of Pulmonary Function in Alpha-1-Antitrypsin Deficiency: Residual Family

Resemblance beyond the Effects of the Pi Locus

Silverman, E.K.; Province, M.A.; Campbell, E.J.; Pierce, J.A.; Rao, D.C 340

Application of DNA Fingerprinting to Parentage and Extended Family Relationship

Testing

Honma, M.; Ishiyama, 1356

$\mathrm{C} 3, \mathrm{BF}$ and $\mathrm{C} 4$ Polymorphisms in Tunisians

Ayed, K.; Gorgi, Y 363

Studies on Four Restriction Fragment Length Polymorphisms of the Type I Collagen Genes in Two Italian Populations

Pepe, G; Muglia, M.; Brancati, C; Modiano, G 368

Association of $\mathrm{ABO}$ and $\mathrm{Rh}(\mathrm{D})$ Blood Groups with Filariasis

Srikumari Srisailapathy, C.R.; Ramesh, A.; Ganesan, J 381

Frequency of the CHE1*K Allele of Serum Cholimesterase in a Sample from Southern

Brazil

Alcantara, V.M.; Chautard-Freire-Maia, E.A.; Picheth, G.; Vieira, M.M 386

Author Index 391 
Subject Index 393

S. Karger $\cdot$ Medical and Scientific Publishers

Basel $\cdot$ München $\cdot$ Paris $\cdot$ London $\cdot$ New York $\cdot$ New Delhi $\cdot$ Bangkok $\cdot$ Singapore $\cdot$ Tokyo

Sydney

Drug Dosage

The authors and the publisher have exerted every effort to ensure that drug selection and dosage set forth in this text are in accord with current recommendations and practice at the time of

publication. However, in view of ongoing research, changes in government regulations, and the constant flow of information relating to drug therapy and drug reactions, the reader is urged to check the package insert for each drug for any change in indications and dosage and for added warnings and precautions. This is particularly important when the recommended agent is a new and/or infrequently employed drug.

All rights reserved.

No part of this publication may be translated into other languages, reproduced or utilized in any form or by any means, electronic or mechanical, including photocopying, recording, microcopying, or by any information storage and retrieval system, without permission in writing from the publisher or, in the case of photocopying, direct payment of a specified fee to the Copyright Clearance Center (see 'Information for Readers and Subscribers').

(C) Copyright 1990 by

S. Karger AG, P.O. Box, CH-4009 Basel (Switzerland) Printed in Switzerland by Buchdruckerei Basler Zeitung + Basler Nachrichten AG, Basel 